\title{
Health Promotion in Obstructive Sleep Apnea Syndrome
}

\author{
Camila de Castro Corrêa ${ }^{1}$ Wanderléia Quinhoneiro Blasca ${ }^{1}$ Giédre Berretin-Felix ${ }^{1}$
}

1 Department of Speech-Language Pathology and Audiology, Bauru School of Dentistry, Universidade de São Paulo, Bauru, São Paulo, Brazil

Int Arch Otorhinolaryngol 2015;19:166-170.

\begin{abstract}
Address for correspondence Camila de Castro Corrêa, BS, MS, Department of Speech-Language Pathology and Audiology, Bauru School of Dentistry, University of São Paulo, Octávio Pinheiro Brisola Street, Bauru, Sao Paulo 17012-901, Brazil

(e-mail: camila.ccorrea@hotmail.com; camilacorrea@usp.br).
\end{abstract}

\author{
Abstract \\ Keywords \\ - health education \\ - sleep apnea \\ - obstructive \\ - sleep disorders \\ - speech \\ - language and hearing \\ sciences
}

Introduction Obstructive sleep apnea syndrome (OSAS), which is commonly underdiagnosed, has a high occurrence in the world population. Health education concerning sleep disorders and OSAS should be implemented.

Objectives The objective was to identify studies related to preventive actions on sleep disorders, with emphasis on OSAS.

Data Synthesis A literature review was conducted using Lilacs, Medline, PubMed, and Scopus by combining the following keywords: "Health Promotion," "Sleep Disorders," "Primary Prevention," "Health Education," and "Obstructive Sleep Apnea Syndromes." Initially, 1,055 papers, from 1968 to 2013, were located, with the majority from the Scopus database. The inclusion criteria were applied, and four articles published between 2006 and 2012 were included in the present study.

Conclusions The studies on preventive actions in sleep disorders, with emphasis on OSAS, involved the general population and professionals and students in the health field and led to increased knowledge on sleep disorders and more appropriate practices.

\section{Introduction}

Sleep disorders are characterized by alterations in sleep that affect the quality of life and the execution of the individual's daily activities. ${ }^{1}$ Such disorders include sleeplessness, nocturnal bruxism, narcolepsy, somniloquy, nocturnal enuresis, parasomnias, night terror, restless legs syndrome, sleepwalking, and obstructive sleep apnea syndrome (OSAS). ${ }^{2,3}$

OSAS has demonstrated increased occurrence in the worldwide population. Studies on the prevalence of OSAS have been performed in several places of the world, considering child and adult populations, although without standardization of methods or procedures. In children, OSAS prevalence was found to be between 0.8 and $2.8 \%$; however, the prevalence was higher in oral breathing and obese children. ${ }^{5-7}$ In the adult population, a prevalence of 2 to $26 \%$ was observed, ${ }^{8-13}$ increasing from 39 to $71 \%$ in obese adults. $^{14}$

received

May 9, 2014 accepted after revision

August 25, 2014

published online

January 26, 2015

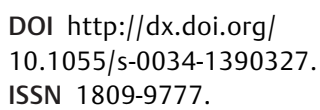

DOI http://dx.doi.org/ 10.1055/s-0034-1390327. ISSN $1809-9777$.

In Brazil, only one study on the prevalence of OSAS used polysomnography, considered the highest standard for the diagnosis of such condition. The sample of 1,042 volunteers, aged 20 to 80 years, resulted in $32.8 \%$ of the participants diagnosed with OSAS. This study presents findings of higher OSAS prevalence as compared with the above-mentioned studies. $^{15}$

Besides the OSAS effect during sleep (i.e., intermittent hypoxemia, transient hypercapnia, and frequent waking), ${ }^{16}$ other implications such as attention deficit in the learning process and in auditory memory and alteration of the tonicity of orofacial myofunctional muscles may be observed. ${ }^{17-20}$ It is worth mentioning the consequences affecting the population, such as decreased job productivity and increased work and traffic accidents. ${ }^{21-23}$

Studies demonstrated low rates of OSAS diagnosis, ${ }^{24}$ noting that $95 \%$ of the individuals were not identified due to the lack of general knowledge and specific knowledge on sleep

Copyright $\odot 2015$ by Thieme Publicações License terms Ltda, Rio de Janeiro, Brazil

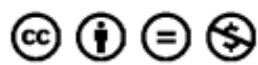


disorders by health care professionals. ${ }^{25-31}$ Thus, health education is needed for the identification of OSAS symptoms directed to the general population, as well as to health care professionals, aiming at better diagnosis and earlier detection through specific protocols.

Therefore, the purpose of the present work was to identify studies involving preventive health care to sleep disorders, with emphasis on OSAS.

\section{Review of Literature}

The literature review was done by searching the databases Lilacs, Medline, PubMed, and Scopus, using the following DeCS/MeSH keywords: (1) "Sleep Disorders"; (2) "Sleep Apnea Syndromes"; (3) "Health Promotion"; (4) "Health Education"; (5) "Primary Prevention." Their respective terms in Portuguese were also used for the database Lilacs.

Six matches of two keywords were used each time in all the databases selected. The keywords were separated by the word "AND" in blank search. The combinations were: 1,3 (combination 1); 1,4 (combination 2); 1, 5 (combination 3); 2, 3 (combination 4); 2, 4 (combination 5); and 2, 5 (combination 6).

The following inclusion criteria were elected: specific studies concerning preventive actions for health promotion on sleep disorders; emphasis on OSAS; maximum amount of information to people about such clinical condition. Studies about health promotion on sleep disorders were included because general information implies favorable attitudes regarding the quality of sleep, such as sleep hygiene, which is a way of preventing OSAS. The exclusion criteria involved literature review and the approach of only the diagnostic evaluation/treatment of subjects with OSAS or other sleep disorders.

For this analysis, titles and abstracts of the works found were read, and, when they met the inclusion criteria, the works were read in full and analyzed as to their objectives, methods, results, and conclusion. The search was carried out without time limitation.

\section{Results}

In all, 1,055 articles from 1968 to 2013 were found, of which 159 articles were located in Medline, 7 in Lilacs, 173 in PubMed, and 716 in the Scopus databases. - Fig. 1 shows the percentages related to the results found in these databases.

The results of the articles located through the combination of the keywords DeCS/MeSH, considering all the databases, are shown in - Table 1 .

Thus, the titles of the 1,055 works found were read, and 991 were discarded through the exclusion criteria. Of the 64 abstracts read, 47 were not considered; 17 seemed to meet the inclusion criteria were read in full, resulting in the exclusion of another 13 additional articles. This way, 4 articles were effectively included in the present study, and the results obtained through the analysis of the selected articles, concerning the purpose, methods, results, and conclusion, are shown in - Table 2. One article was located in Lilacs, one in PubMed, and two in Scorpus; two were published in 2006, one in 2009, and one in 2012.

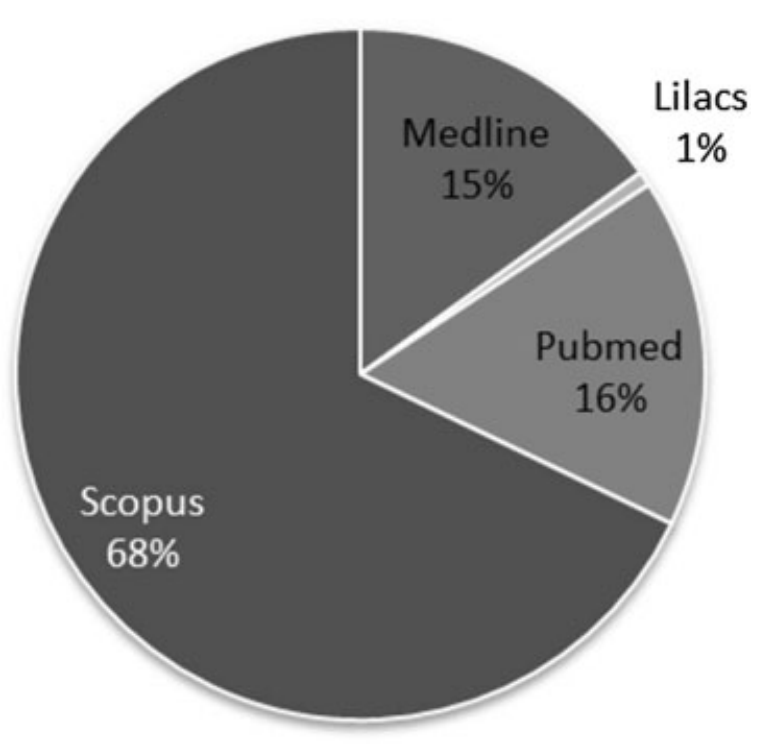

Fig. 1 Percentages of the results obtained in the databases consulted.

Table 1 Articles found through the combination of keywords in the databases searched in this study

\begin{tabular}{|l|l|}
\hline $\begin{array}{l}\text { Combination of the keywords } \\
\text { DeCS/MeSH }\end{array}$ & $\begin{array}{l}\text { Number of articles } \\
\text { found }\end{array}$ \\
\hline Combination 1 & 363 \\
\hline Combination 2 & 354 \\
\hline Combination 3 & 114 \\
\hline Combination 4 & 71 \\
\hline Combination 5 & 65 \\
\hline Combination 6 & 88 \\
\hline Total & 1,055 \\
\hline
\end{tabular}

\section{Discussion}

Considering the high prevalence of OSAS and the low rate of diagnosis, it is important to highlight the value of the studies directed to health education intended for the population in general and for health care professionals, enlarging the access to reliable and current information, focusing on assertive evaluation, and, mainly, guiding measures of prevention to this condition.

Based on the articles found in the search for this study, more results were observed in the Scopus database and fewer in the Lilacs database. Most publications were found in the SciVerse Scopus, as its scope is international, with more than 18,000 titles of 5,000 international publishing companies, and it provides author and institution profiles, citation tracking, h-index, and journal analyzer. Moreover, articles in press of more than 3,000 periodicals are available-that is, those articles that were accepted but have not yet appeared in a regular edition of the journal. ${ }^{36}$ On the other hand, the Lilacs database, through which fewer works were obtained, restricts its scope to Latin America and the Caribbean and has 
Table 2 Analysis of the articles included, concerning the objective, methods, results, and conclusion

\begin{tabular}{|c|c|c|c|c|}
\hline Author, year & Purpose & Methods & Results & Conclusion \\
\hline Conway et al. ${ }^{32}$ & $\begin{array}{l}\text { To promote a campaign } \\
\text { to increase the aware- } \\
\text { ness on sleep disorders }\end{array}$ & $\begin{array}{l}\text { Resources of media, } \\
\text { exhibits, and lessons } \\
\text { were used to reach } \\
2,000,000 \text { people and } \\
55,000 \text { health profes- } \\
\text { sionals, evaluating the } \\
\text { referrals made after the } \\
\text { information was sup- } \\
\text { plied in a hospital. }\end{array}$ & $\begin{array}{l}\text { A slight increase in the } \\
\text { diagnosis of obstructive } \\
\text { sleep apnea syndromes } \\
\text { was observed, among } \\
\text { other sleep disorders, } \\
\text { through the referrals } \\
\text { made. }\end{array}$ & $\begin{array}{l}\text { Health professionals } \\
\text { seemed to have a higher } \\
\text { understanding of sleep } \\
\text { disorders. }\end{array}$ \\
\hline Stremler et al. ${ }^{33}$ & $\begin{array}{l}\text { To assess the viability } \\
\text { and acceptability of } \\
\text { information about sleep } \\
\text { by postpartum mothers }\end{array}$ & $\begin{array}{l}\text { Behavioral-educational } \\
\text { intervention with } \\
\text { first-time mothers in the } \\
\text { postpartum period was } \\
\text { performed by nurses, } \\
\text { on sleep information, by } \\
\text { means of a book. }\end{array}$ & $\begin{array}{l}\text { Children from the sleep } \\
\text { intervention group had } \\
\text { less nocturnal waking } \\
\text { and more total sleep } \\
\text { time. }\end{array}$ & $\begin{array}{l}\text { A more adequate sleep } \\
\text { was provided for both } \\
\text { mother and child. }\end{array}$ \\
\hline $\begin{array}{l}\text { Moseley and } \\
\text { Gradisar }^{34}\end{array}$ & $\begin{array}{l}\text { To investigate the effec- } \\
\text { tiveness of an interven- } \\
\text { tion in the increase of } \\
\text { knowledge about sleep } \\
\text { directed to adolescents }\end{array}$ & $\begin{array}{l}\text { Adolescents received } \\
\text { four lessons on promo- } \\
\text { tion and maintenance of } \\
\text { a healthy lifestyle, } \\
\text { reflecting on the quality } \\
\text { of sleep. }\end{array}$ & $\begin{array}{l}\text { The program increased } \\
\text { the adolescents' knowl- } \\
\text { edge about sleep. }\end{array}$ & $\begin{array}{l}\text { The interventions } \\
\text { proposed for the ado- } \\
\text { lescents, emphasizing } \\
\text { the reduction of practi- } \\
\text { ces that are detrimental } \\
\text { to sleep, were valid. }\end{array}$ \\
\hline Bandla et al. ${ }^{35}$ & $\begin{array}{l}\text { To compare the level of } \\
\text { satisfaction and } \\
\text { economic factor on } \\
\text { sleep medicine, } \\
\text { presented virtually and } \\
\text { in a face-to-face format }\end{array}$ & $\begin{array}{l}\text { Medical students were } \\
\text { instructed on sleep } \\
\text { medicine in one of the } \\
\text { two formats: face- } \\
\text { to-face or online } \\
\text { modules. }\end{array}$ & $\begin{array}{l}\text { The pupils who partici- } \\
\text { pated in the face-to-face } \\
\text { format were more } \\
\text { satisfied than those who } \\
\text { participated online. The } \\
\text { learning and its costs } \\
\text { were approximately } \\
\text { equivalent for both } \\
\text { formats. }\end{array}$ & $\begin{array}{l}\text { The results between the } \\
\text { two methodologies } \\
\text { were similar, with the } \\
\text { online platform being } \\
\text { economical and } \\
\text { educationally feasible. }\end{array}$ \\
\hline
\end{tabular}

contributed for 27 years to the increase of the visibility, access, and quality of health information. ${ }^{37}$

A difference in the results obtained in relation to the amount of articles found, when using six different combinations, was verified. When combination 3 was used, in the English and Portuguese languages, more results were verified, whereas with combination 6 , fewer results were found. Such findings can be justified by the fact that "Health Promotion" represents a wider concept, including the objective of an excellent level of life and health, and "Primary Prevention" presents the objective for illness prevention, ${ }^{38}$ according to modern concepts of health promotion and primary care, initiated after the Ottawa Charter for Health Promotion. ${ }^{39}$

After the 1,055 articles were read, 93.9\% of the articles were excluded in this first stage, for even using keywords and specific combinations related to health promotion, sleep disorders, and OSAS, many of the studies were aimed at the diagnosis, assessment, treatment, and characterization of OSAS cases and other sleep disorders. This finding suggests that the scientific research has prioritized investigations directed to diagnosis and intervention. On the other hand, in the area of health, the importance of health promotion has been described as well, although unplanned actions have been observed or restricted to a certain number of people, ${ }^{40,41}$ thus limiting the results achieved.
Only recent articles, dating from 2006 to 2012, composed the results of this work, thus the theme is quite current. Moreover, the actions taken were directed not only to health professionals, but also to doctors, ${ }^{32}$ medical students, ${ }^{35}$ postpartum mothers, ${ }^{33}$ and adolescents. ${ }^{34}$ The value of the actions directed to professionals/students in the area of health, such as pharmacists ${ }^{42}$ and pediatricians, ${ }^{43}$ is highlighted, due to their qualification on sleep disorders, so as to improve the diagnosis of OSAS. Actions are also important for the general population, including children and adolescents, because of their increased risk of OSAS caused by behaviors that are detrimental to a good quality of sleep, such as insufficient amount of sleep, television sets in the bedroom, and late and variable bedtimes. ${ }^{44}$

The studies presented several methods in the transmission of knowledge, such as lessons in the face-to-face format, ${ }^{34,35}$ online modules, book discussions, ${ }^{33}$ and media and exhibit resources. $^{32}$ IThe possibility of doing an online screening of those at risk of OSAS was noted, ${ }^{45}$ as well as guidance to assist parents in dealing with the diagnosis of insomnia, by means of the Mini-Kiss online. ${ }^{46}$ The positive results obtained through localized actions support the need for specific methods for health education according to the profile of the target public.

In the four selected studies, increased sleep knowledge by adolescents and medical students after the actions was 
verified, $^{34,35}$ as well as increased rate of diagnosis of mild OSAS and other nocturnal sleep disorders, ${ }^{32}$ reduction of waking, and increased nocturnal sleep in babies. ${ }^{33}$ Such findings show that planning actions for the diagnosis of OSAS directed to the largest number of individuals is paramount, as in the study of Conway et al. ${ }^{32}$ Teaching about suitable treatments and incentives for the appropriate procedures in each case is also important, ${ }^{4-49}$ demonstrating that an assertive diagnosis should be associated with a successful treatment.

Only articles in Portuguese, English, and Spanish were selected after the headings of the articles were read. Thus, the language of the works was not a limiting factor for the research. Moreover, the search in the Virtual Private Network system, which provides a myriad of journals, enabled the reading in full of all selected articles, a contributing factor for the development of the study.

In addition to the investigation of articles published on preventive actions to health care, future studies be performed investigating Web sites related to the subject, as well as actions by official scientific organizations in the field of sleep medicine. Hence, reliable information regarding education on health aimed at OSAS can be found, such as the actions promoted in World Sleep Day in the official Web site and organized by the World Association of Sleep Medicine, which aims at emphasizing the importance of quality of sleep. ${ }^{50}$

The lack of scientific studies focusing on health promotion in OSAS demonstrates that further research using this approach, directed to both professionals and the population, is necessary, aiming at minimizing the consequences that such clinical condition brings to those affected.

\section{Final Comments}

A literature review of studies on health promotion specifically involving preventive actions of health care in sleep disorders, with emphasis on OSAS, was presented. Four studies that increased the knowledge of the population, professionals, and health care students on health and sleep disorders were found, promoting assertive referrals by health care professionals and the adherence of the population to more favorable behaviors, aiming at suitable sleep.

\section{References}

1 Di Francesco RC, Forts FSG, Komatsu CL. Improvement of the quality of life in children after adenoamigdalectomia. Rev Bras Otorrinolaringol (Engl Ed) 2004;70(6):748-751

2 Hasan R, Haddad FLM, Aloe F, Tavares S. Upheavals of sleep. Rev Bras Med 2009;66(12):31-40

3 Sander HH, Pachito DV, Vianna LS. Outros distúrbios do sono na Síndrome da Apnéia do Sono. Medicina (Ribeirão Preto) 2006; 39(2):205-211

4 Marcus CL, Brooks LJ, Ward SD, et al. Diagnosis and management of childhood obstructive sleep apnea syndrome. Pediatrics 2012; 130(3):714-755

5 Izu SC, Itamoto $\mathrm{CH}$, Pradella-Hallinan M, et al. Obstructive sleep apnea syndrome (OSAS) in mouth breathing children. Braz J Otorhinolaryngol 2010;76(5):552-556
6 Wing YK, Hui SH, Pak WM, et al. A controlled study of sleep related disordered breathing in obese children. Arch Dis Child 2003; 88(12):1043-1047

7 Rhodes SK, Shimoda KC, Waid LR, et al. Neurocognitive deficits in morbidly obese children with obstructive sleep apnea. J Pediatr 1995;127(5):741-744

8 Bixler EO, Vgontzas AN, Lin HM, et al. Prevalence of sleep-disordered breathing in women: effects of gender. Am J Respir Crit Care Med 2001;163(3 Pt 1):608-613

9 Durán J, Esnaola S, Rubio R, Iztueta A. Obstructive sleep apneahypopnea and related clinical features in a population-based sample of subjects aged 30 to 70 yr. Am J Respir Crit Care Med 2001;163(3 Pt 1):685-689

10 Ip MS, Lam B, Tang LC, Lauder IJ, Ip TY, Lam WK. A community study of sleep-disordered breathing in middle-aged Chinese women in Hong Kong: prevalence and gender differences. Chest 2004;125(1):127-134

$11 \mathrm{Kim} \mathrm{J}$, In K, Kim J, et al. Prevalence of sleep-disordered breathing in middle-aged Korean men and women. Am J Respir Crit Care Med 2004;170(10):1108-1113

12 Bearpark H, Elliott L, Grunstein R, et al. Snoring and sleep apnea. A population study in Australian men. Am J Respir Crit Care Med 1995;151(5):1459-1465

13 Udwadia ZF, Doshi AV, Lonkar SG, Singh CI. Prevalence of sleepdisordered breathing and sleep apnea in middle-aged urban Indian men. Am J Respir Crit Care Med 2004;169(2):168-173

14 Lima Filho JA, Ganem EM, Cerqueira BGP. Reavaliação da via aérea do paciente obeso submetido à cirurgia bariátrica após a redução do índice de massa corpórea. Rev Bras Anestesiol 2011;61(1): 31-40

15 Tufik S, Santos-Silva R, Taddei JA, Bittencourt LRA. Obstructive sleep apnea syndrome in the Sao Paulo Epidemiologic Sleep Study. Sleep Med 2010;11(5):441-446

16 American Academy of Sleep Medicine. Sleep-related breathing disorders in adults: recommendations for syndrome definitions and measurements techniques in clinical research. Sleep 1999; 22(5):667-689

17 Weber SAT, Lima Neto AC, Ternes FJS, Montovani JC. Distúrbio de hiperatividade e déficit de atenção na síndrome de apnéia obstrutuiva do sono: há melhora com tratamento cirúrgico? Rev Bras Otorrinolaringol (Engl Ed) 2006;72(1):124-129

18 Uema SFH, Pignatari SSN, Fujita RR, Moreira GA, Pradella-Hallinan M, Weckx L. Avaliação da função cognitiva da aprendizagem em crianças com distúrbios obstrutivos do sono. Rev Bras Otorrinolaringol (Engl Ed) 2007;73(3):315-320

19 Martins CH, Castro Júnior Nd, Costa Filho OA, Souza Neto OM. Obstructive sleep apnea and P300 evoked auditory potential. Braz J Otorhinolaryngol 2011;77(6):700-705

20 Guimarães KC, Drager LF, Genta PR, Marcondes BF, Lorenzi-Filho G. Effects of oropharyngeal exercises on patients with moderate obstructive sleep apnea syndrome. Am J Respir Crit Care Med 2009;179(10):962-966

21 Rajaratnam SM, Barger LK, Lockley SW, et al; Harvard Work Hours, Health and Safety Group. Sleep disorders, health, and safety in police officers. JAMA 2011;306(23):2567-2578

22 Koyama RG, Esteves AM, Oliveira e Silva L, et al. Prevalence of and risk factors for obstructive sleep apnea syndrome in Brazilian railroad workers. Sleep Med 2012;13(8):1028-1032

23 Amra B, Dorali R, Mortazavi S, et al. Sleep apnea symptoms and accident risk factors in Persian commercial vehicle drivers. Sleep Breath 2012;16(1):187-191

24 Fuhrman C, Fleury B, Nguyên XL, Delmas MC. Symptoms of sleep apnea syndrome: high prevalence and underdiagnosis in the French population. Sleep Med 2012;13(7):852-858

25 Mercado JC. Identifying obstructive sleep apnea: a highly prevalent and underdiagnosed disease. Physician Assist 2003;27(2): $39-45$ 
26 Hoffstein V, Mateika S, Anderson D. Snoring: is it in the ear of the beholder? Sleep 1994;17(6):522-526

27 Camargo EP, Carvalho LBC, Prado LBF, Prado GF. Is the population properly informed about sleep disorders? Arq Neuropsiquiatr 2013;71(2):92-99

28 Haponik EF, Frye AW, Richards B, et al. Sleep history is neglected diagnostic information. Challenges for primary care physicians. J Gen Intern Med 1996;11(12):759-761

29 Stores G, Crawford C. Medical student education in sleep and its disorders. J R Coll Physicians Lond 1998;32(2):149-153

30 Papp KK, Penrod CE, Strohl KP. Knowledge and attitudes of primary care physicians toward sleep and sleep disorders. Sleep Breath 2002;6(3):103-109

31 Uong EC, Jeffe DB, Gozal D, et al. Development of a measure of knowledge and attitudes about obstructive sleep apnea in children (OSAKA-KIDS). Arch Pediatr Adolesc Med 2005;159(2):181-186

32 Conway SG, Tufik S, Frussa Filho R, Bittencourt LR. Repercussions of a sleep medicine outreach program. Braz J Med Biol Res 2006; 39(8):1057-1063

33 Stremler R, Hodnett E, Lee K, et al. A behavioral-educational intervention to promote maternal and infant sleep: a pilot randomized, controlled trial. Sleep 2006;29(12):1609-1615

34 Moseley L, Gradisar M. Evaluation of a school-based intervention for adolescent sleep problems. Sleep 2009;32(3):334-341

35 Bandla H, Franco RA, Simpson D, Brennan K, McKanry J, Bragg D. Assessing learning outcomes and cost effectiveness of an online sleep curriculum for medical students. J Clin Sleep Med 2012;8(4):439-443

36 Base de dados SciVerse Scopus. Available at: www.scopus.com/ scopus/home.url. Accessed September 12, 2013

37 Base de dados Lilacs. Available at: http://lilacs.bvsalud.org/. Accessed September 12, 2013

38 Demarzo MMP, Aquilante AG. Saúde escolar e escolas promotoras de saúde. In: Programa de Atualização em Medicina de Família e Comunidade. Porto Alegre. Art Med 2008;3:49-76

39 Zilbovicius C, Gonçalves DA. Reorganização dos sistemas de saúde. Unidades de Conteúdo UNIFESP/UNASUS/PROVAB. 2011. Available at: http://www.unasus.unifesp.br/biblioteca_virtual/esf/2/unidades_conteudos/unidade02/unidade02.pdf. Accessed September 12, 2013

40 Veras RP. Prevenção de doenças em idosos: os equívocos dos atuais modelos. Cad Saude Publica 2012;28(10):1834-1840

41 Traverso-Yépez MA. Dilemmas on Health promotion in Brazil: considerations on the national policy. Interface Comunic Saúde Educ 2007;11(22):223-238

42 Tran A, Fuller JM, Wong KK, Krass I, Grunstein R, Saini B. The development of a sleep disorder screening program in Australian community pharmacies. Pharm World Sci 2009;31(4): 473-480

43 Owens JA, Dalzell V. Use of the "BEARS" sleep screening tool in a pediatric residents' continuity clinic: a pilot study. Sleep Med 2005;6(1):63-69

44 Mindell JA, Owens J, Alves R, et al. Give children and adolescents the gift of a good night's sleep: a call to action. Sleep Med 2011; 12(3):203-204

45 Hwang KO, Hamadah AM, Johnson CW, Thomas EJ, Goodrick GK, Bernstam EV. Screening for obstructive sleep apnea on the internet: randomized trial. Am J Med 2009;122(10):e1-e6

46 Schlarb AA, Brandhorst I. Mini-KiSS Online: an Internet-based intervention program for parents of young children with sleep problems-influence on parental behavior and children's sleep. Nat Sci Sleep 2012;4:41-52

47 Dombrowsky JW, Williams SG, Wickwire E, Lettieri CJ. Strategies to enhance adherence to PAP therapy for OSA. Clinical Pulmonary Medicine 2013;20(1):21-28

48 Olsen S, Smith SS, Oei TPS, Douglas J. Motivational interviewing (MINT) improves continuous positive airway pressure (CPAP) acceptance and adherence: a randomized controlled trial. J Consult Clin Psychol 2012;80(1):151-163

49 Smith SS, Lang CP, Sullivan KA, Warren J. A preliminary investigation of the effectiveness of a sleep apnea education program. J Psychosom Res 2004;56(2):245-249

50 Day WS. World Sleep Day, good sleep, healthy aging. Available at: http://www.worldsleepday.org/ Accessed September 18, 2013 